\title{
Understanding Education Involving Geovisual Analytics
}

\author{
Linnea Stenliden \\ Linköping University, Norrköping, Sweden
}

linnea.stenliden@liu.se

Executive Summary

Handling the vast amounts of data and information available in contemporary society is a challenge. Geovisual Analytics provides technology designed to increase the effectiveness of information interpretation and analytical task solving. To date, little attention has been paid to the role such tools can play in education and to the extent to which they can process actionable data for students. The aim of this paper is to examine students' learning activities involving a Geovisual Analytics tool in order to understand education in such settings. The paper builds on a study conducted in three public primary schools in grades 4 through 6 . The implemented technology was used in four different social science classes, each for a period of two to four weeks. Empirical data were collected via video observations and speak-aloud interviews conducted using software that allows recordings by computer webcams and captures the actions on the computer screen. The interactions were analyzed, applying constructs and metaphors developed by Latour. The results indicate that, together, the data-rich setting and the students create intelligibility, where knowledge emerges from heterogeneously constructed networks. These show that learning is complex in character, continuously ongoing in an intertwined, multimodal, multiple, and contentfocused mode.

Keywords: Geovisual Analytics; data; visual storytelling; learning activities; multiple learning; education, educational practices

\section{Introduction}

Big data and information have lately been introduced as society's next frontier for innovation, competition, and productivity (Manyika et al., 2011). In daily life, people have to face the challenge of sorting, filtering, interpreting, and evaluating huge quantities of information (Hilbert \& López, 2011). Accordingly, there has been an increase in what society expects students of all ages to learn and manage as abstract knowledge (Ludvigsen, 2011). At the same time, there is increasing evidence that our information skills are not keeping pace in any systematic fashion

Material published as part of this publication, either on-line or in print, is copyrighted by the Informing Science Institute. Permission to make digital or paper copy of part or all of these works for personal or classroom use is granted without fee provided that the copies are not made or distributed for profit or commercial advantage AND that copies 1) bear this notice in full and 2) give the full citation on the first page. It is permissible to abstract these works so long as credit is given. To copy in all other cases or to republish or to post on a server or to redistribute to lists requires specific permission and payment of a fee. Contact Publisher@InformingScience.org to request redistribution permission.
(Chakravarty, 2008). Alongside the raised expectations there is a hope that the rapidly growing percentage of tasks that are or could be augmented by the use of information communication technology (ICT) will solve some of the problems with managing information (Harper, Rodden, Rogers \& Sellen, 2008). Research indicates that Websupported education can provide access to rich and varied information sources 
and can free students to search for, select, and organize information (Sundin \& Johannisson, 2005). However, studies also indicate that assessing the credibility and authority of information sources in Web environments can cause serious problems for students (Limberg, Alexandersson, \& Lantz Andersson, 2008; Sundin, Julien, Limberg, \& Rieh, 2008). Evidence exists that in the worst cases such environments can even damage learning (Ainsworth, 2008). Overall, there is little evidence that computer-aided instruction improves classroom outcomes significantly (Angrist \& Lavy, 2002; Rouse, Krueger, \& Markham, 2004). Consequently, it is increasingly important to improve education and technology in order to make it easier for teachers and students to access, organize, evaluate, and process data and information to enhance learning.

Geovisual Analytics (short for Geospatial Visual Analytics) has developed in order to deal with some of these challenges (Andrienko et al., 2010). The research area aims at providing tools, Geovisual Analytics, with connections to relevant data that reinforce analytical reasoning, argumentation, and knowledge building (Tomaszewski, 2008) by enhancing purely visual and interactive methods (Keim et al., 2008). Furthermore, knowledge communication using publishing and storytelling methods is also of significance for the field of Geovisual Analytics (Andrienko et al., 2010). The technology has so far been used outside of education, and data-informed instruction has always assumed that the primary user of data is the policy-maker or supervisor (Halverson \& Shapiro, 2012). The suggestion is that educational practices and research should move toward investigations of these kinds of technologies, to gain knowledge about possible potentials and pitfalls for students' learning. Therefore, these tools have lately been applied also to educational activities in schools (Jern, 2010; Stenliden \& Jern 2010).

As technology, implemented in different settings, is never passive (Heidegger, 1977), there is a need to understand how technology affects and reshapes learning and education (Bijker, 2010). This means that, although technology (e.g., computers) may be found to be very helpful, it requires an understanding of what happens in the system as a whole. The best data allow us not only to assess performance - of students, educators, or technology - but also to understand the processes that could improve learning and education (Tucker, 2010). Fenwick and Edwards (2010) argue that these processes are implied as activities dependent on the form of interactions among the different actors in the educational environment, and that these interactions play a fundamental role in the development of learning and knowledge. Clear relationships have been found in learning activities between data/information types, tools/information sources, individuals, and context, and these actors all have implications for the data-use process (Byström, 1999; Sundin, \& Johannisson, 2005).

Hence, the aim of this paper is to examine students' learning activities involving a Geovisual Analytics tool in order to understand this kind of education. It focuses on relationships among different actors and how actions are carried out; the interactions between data - information around social science content, the tool - a Geovisual Analytics tool - the Open Statistics eXplorer platform, and the individuals - students and teachers in primary school classrooms. Integrating technologies for learners into public schools like this may help to demonstrate how digital technologies can reshape learning in and out of schools (Halverson \& Shapiro, 2012).

The first section of this paper gives a short overview of the applied theory in the study - the actor-network theory (ANT) (Latour, 2007; Law, 1992). In the next section, I briefly go through some notions of education and characteristics of learning. In the empirical part, I describe the study's design, method, and analysis, and then, by giving examples of actors' interactions, present the results. Finally, in the conclusion, I elaborate on some of the findings and discuss them in relation to the technology's role in the produced learning activities. 


\section{Learning in Networks beyond the Dichotomy of the Social and Material}

Drawing on the postmodern and post-humanistic views, this study is inspired by the actornetwork theory (ANT) (Latour, 1996). ANT is not to be looked upon as a homogeny and straightforward theory. During the years there are many researchers who have contributed to this theory with new concepts and many of the old terms have been negotiated. ANT is not a learning theory as such, but a theory of knowledge, agency, and machines (Law, 1992). It assumes that learning takes place between people and their technologies, and that knowledge changes hands through interactions between these. It is embodied in mechanical devices and social practices that are networked together, acting as one (Edwards, Biesta, \& Thorpe, 2009). ANT is relational, processoriented, and treats agents, organizations, and devices as interactive effects (Law, 1992).

The study builds on previous efforts to analyze how vision and learning operate as, for example, in the work of Goodwin (1994), Lave and Wenger (1991), and Engeström and Miettinen (1999). However, in this study's view learning is produced beyond the boundaries of the dichotomy of the social and material. It considers social and material factors to be of equal importance (Pinch $\&$ Bijker, 1987). By removing the analytical divide between humans and non-human objects, researchers are better able to examine the nature of these actors' actions (Callon, 1986; Latour, 1992).

When ANT is applied, as it is in this study, to an understanding of contexts for education, the learner and the learning process are seen in distinct ways. The learner is seen not so much as an individual, possessing typical cognitive capacities, but as a participant in networks of practices. The learning process is understood as a network effect, where the network in question is understood as heterogeneous, comprising bits and pieces of materials (technologies, information, texts, furniture), human institutions (school, language, social relations), and interactions with humans (students, teachers, principals).

The primary building blocks of actor-networks are the interactions between the actors, or rather, actants. To open up for an analogous treatment of social and material objects and their relations, the term actant is used in this paper. The diverse actants produce effects, add multiplicity, and offer propositions. The networks emerge from the actions of actants within the network and their ability to align in pursuit of their interests. Their many manifestations are called translations. So, one way to study this is to follow, for example, a cursor moving on a computer screen, a student who follows the cursor, a word that is highlighted by the cursor, the articulation on which the student focuses, etc. One can only share in the action and distribute it with other actants (Callon 1986, Latour 1996).

In some cases, actor-networks can become so transparent or accepted that they are no longer recognized. In this case, alignment and durability lead to punctualization, a point where the network supporting an actant disappears from view, as when, for example, we use a calculator for a mathematical calculation. The calculator transforms the keystrokes into a hidden operation and the screen offers a result immediately. Poorly aligned actants, on the other hand, require frequent negotiation of their interactions or they may cease to interact. Challenges to the alignment between actants in a network are termed trials by strength (Latour, 1996).

A human actant processes such attributes of actant-ship as initiatory capacity, rationality, and the ability to make choices (Biesta, 1995). Enrollment is the definition and distribution of human roles in a network. Agency and roles are not fixed and pre-established, nor are they necessarily successfully imposed (Fenwick \& Edwards, 2010).

So, the main tenet is that actants themselves in interactions make everything, including the frames and context. Instead of thinking in terms of surfaces (two-dimensions) or spheres (three- 
dimensions), it is better to think of networks in terms of nodes that have as many dimensions as they have connections. Altogether, with this theoretical framework, possibilities for a transgression of the binaries between social and material can be gained. I was better able to examine the nature of all these actors' actions. The approach can therefore give new insights on learning activities with and comprehensions of technology such as Geovisual Analytics.

\section{Learning and Education - Actants' Activities, Purposes, and Modes}

As this paper tries to understand education involving Geovisual Analytics, it can be helpful to first declare opinions of ideas about learning and education. The view in this paper is that the way education is constructed is determined by the process of learning that takes place, not so much by what is learned.

\section{Learning}

In this study, learning is understood to be dependent on activities in the form of interactions among actants in an environment. These activities are seen to play a fundamental role in the development of learning and knowledge (Fenwick \& Edwards, 2010). The activities are constantly ongoing processes where the students (as actants) try to understand their context or surroundings. In the following, the term learning activity (Lantz-Andersson, 2009) will be used when referring to interactions between the actants since what is studied is how they act/engage in collaborative tasks. The activities studied are those where learning is seen as the consequence. It is a consequence of the actants' alignments as they are created in an intra-play between the tool, the information, and the individuals (Mercer, 1995). Notably, a focus on the tool as an actor - in this case a Geovisual Analytics tool - is a departure from the ways software has typically been treated in research on verbal, non-verbal, and multimodal communication (Djonov \& Van Leeuwen, 2011). Rather than seeing software as a technology for producing or analyzing texts, it is seen as an actant for making meaning that functions alongside semiotics such as verbal and visual language. In this study no distinction is made between material semiotics (Law \& Hassard, 1999) and social semiotics (Kress, 2010). Instead they are seen as co-existing, overlapping and heterogenic. Signs are seen as getting their meaning in relation to other signs. They do not have internal or stable qualities and exist in all modes. Multimodal actants are seen as those that "exceed the alphabetic and may include still and moving images, animations, color, words, music and sound" (Takayoshi \& Selfe, 2007, p 1).

\section{Education}

Organized education can be viewed as a special discourse, where the purpose most often is to enable students to act as competent participants and where the standard goal is that learning takes place (Ludvigsen, 2011). Biesta (2009) claims that education and learning, are quite often used as if they were synonymous. When we conflate the two, learning and education, we lose sight of the fact that "educational learning" is always learning in relation to particular purposes and includes a process and certain content. This is how education is framed (Osberg \& Biesta, 2008).

In order to fulfill the teacher's purpose, the students are commonly required to solve tasks around certain content. Hackman $(1969$, p. 97) wrote that tasks play an important role in much research on learning. Carroll's Time-On-Task hypothesis (Bloom, 1982; Carroll, 1963) adopts the idea that the longer students spend in the process - engaging with the content, the learning materials, and the assignments - the more opportunities the students have to achieve the purpose - to learn. Therefore, if students spend a greater fraction of time "off-task" (engaged in behaviors where learning from the material is not the primary goal), they will spend less time "on-task" and learn 
less. Again, the important question concerns what kind of knowledge counts as learning and what the process used to achieve the purpose should look like (Ludvigsen, 2011).

From the students' perspective the question concerns how to pursue learning in relation to their own purposes, goals, and individual development (Ludvigsen, 2011). Processes are commonly constructed by activities oriented to the object of knowledge and generally also activities that concern how to enroll as a human and as a student (Masschelein, 2012; Winter \& Biesta, 2012). This construction of agency usually occurs during the learning activities as well (Barajas, 2010; Benwell \& Stokoe, 2005).

To summarize, this study views organized education as activities in a process of certain content where the purpose of education can be different for different actors. Students' concepts and knowledge domains are developed through learning activities. Students encounter learning differently with regard to the idea of semiotics, which assumes that all modes are, in principle, of equal significance in communication. This understanding is essential in relation to how to understand education, how to study learning, and how to set up a study. These implications will be shown in the next section, which presents the empirical study.

\section{The Empirical Study}

This section offers an overview of the empirical study and describes the data collection methods as well as ethical considerations and analysis.

\section{Overview of the Study}

The study's design and data collection were chosen with a view to understanding education with Geovisual Analytics during the years of compulsory schooling. The study was carried out in three different primary schools in a municipality in Sweden. Altogether, four teachers and their social science classes (grades 4 through 6) - 98 students $(10-13$ years old) - participated. In phase one, the teachers were introduced to the technology. In phase two, the students worked in pairs, using the tool's educational material in all their social science classes for a period of two to four weeks. The empirical data in this study were collected in phase two. This data; of the interactions of the actants, the learning activities creating the context of this setting, were examined in detail. The main actants were as follows:

Tool - the Open Statistics eXplorer platform, a Geovisual Analytics tool, was used in this study. It has a conceptual approach based on three complementary activities: a) data uploading, b) storytelling, and c) publishing (Ho, Lundblad, Åström, \& Jern, 2011). The visualizations facilitate information and geographical visualization methods. Data, official statistics, are normally preloaded with a set of basic indicators from official databases. The methodological concept allows the educator to customize the content with its storytelling functions and publish a story with the help of a publisher tool on a blog or a web page (Stenliden \& Jern, 2010). The published material is called a "Vislet" (Figure 1). Vislet is short for visualized booklet - a small visualized digital book with an interactive and dyna-linked interface.

Data - Official statistics from the databases Statistic Sweden (SCB), Organisation for Economic Co-operation and Development (OECD), World Health Organisation (WHO), and the World Data Bank were uploaded to the platform. Using the storytelling functions, visualized interactive stories around the data were produced and Vislets were published in a common blog shared by the participating schools (Stenliden, 2011). 


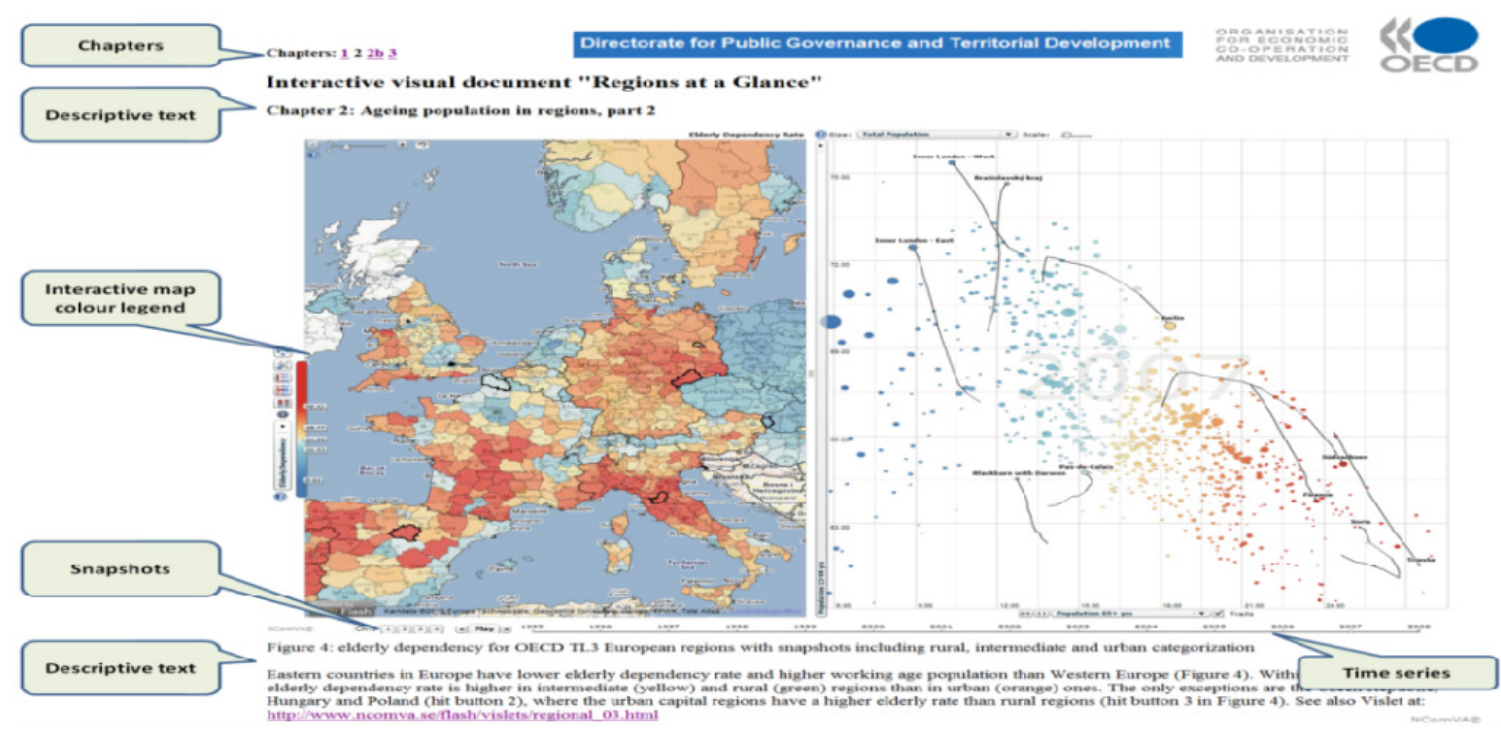

Figure 1. A Vislet based on public Organization for Economic Co-operation and Development (OECD) data. The document includes an educational text as well as a map, motion chart, snapshots, and time series - i.e., the methodological concept.

Individuals - With respect to the post-humanistic educational commitment, where a student is seen as an emerging individual entity and as a participant in networks of practices (Fenwick \& Edwards, 2010), it is most difficult to say anything about the typical student, learning styles and information-seeking styles, or information profiles. The students were, however, attending schools with different catchment areas identified as a) a multilingual area, b) a homogeneous agricultural, and c) a garden suburb. The differences can be seen as bringing a broad platform for the empirical material, but the material has been treated as one entity.

\section{Method}

Methods that advance knowledge of multimodal actants and the ways these actants align and overlap to translate and transform are needed for documentation and analysis of contemporary discourse practices, particularly when studying the use of media technology (Kress, 2010; Latour, 2007). In response to this, two qualitative methods for collecting empirical data were used: video observations (Heath, Hindmarsh, \& Luff, 2010) and speak-aloud interviews (Charters, 2003). These methods made it possible to thoroughly document human actants'/students' and nonhuman actants'/the tool's activities, signs, propositions, expressions, and translations (Jordan \& Henderson, 1995). Altogether, the empirical material collected in this study constitutes 42 filmed sessions from a micro perspective, comprising close-up recordings of students and computer screens ( 22.2 hours), and 35 filmed sessions taking a macro perspective, comprising overview recordings of the classroom (16 hours) and 15 speak-aloud interviews.

\section{Analysis}

An early finding was the simultaneousness of 1) the different kinds of activities related to the object of knowledge, and 2) activities related to human enrollment. Accordingly, a collection from the empirical data was made, organized using Nvivo, software that lets you collect, organize, and analyze data from interviews, video observations, etc, and analyzed further. The focus was on all learning activities in the network and on the qualities they characterize in practical action. Despite that, the presentation of the material in the next section is separated for the sake of clarity. The episodes have been transcribed following the conventions developed in conversation analysis 
(Jefferson, 1985). The original speech is in Swedish. See Moreman (Jefferson, 1985) for a discussion on the field of analyzing foreign language conversations and how to translate transcripts and analyses in different languages. The goal has been to translate the interactions, what the actants do and how they align in these doings, rather than just the human words. Therefore important additional images of the students and the screen have been added to the transcripts. In the following a set of analyses of the actors' learning activities are organized around three themes concerning collaboration in the network. First, I discuss how non-human actants reinforce alignment. Second, I elaborate on how qualities of human enrollment affect the alignment. Third, I deliberate on how these kinds of learning activities and alignments support learning about the object of knowledge.

\section{Results - Learning Activities Developed in the Network}

The presentation of results builds on excerpts drawn from the empirical data to discuss enacted activities in the network. In these excerpts the students' assignment was to identify the top five countries in the world when it comes to emissions of $\mathrm{CO}_{2}$ per capita. In order to conduct an analysis, to be able to emphasize different aspects of the learning activities, the transcript is cut into pieces; however, the excerpts are placed in chronological order.

\section{Network Collaboration - Non Human Actants Reinforce Alignment}

An examination of the learning activities in the network reveals that the students used the Geovisual Analytics' different sort of coding, where data were transformed into information by the technology's articulations, to reinforce their ability to align in the network. The starting point for these learning activities was, for the students, most often searching for a spatial area, a place or an articulation to translate with. This was closely connected to a following activity that frequently ended up in a focusing action. These activities were all combined with the screen's coding, articulation, and highlighting, all perceived and interpreted by the students. A second aspect of the learning activities was the non-human actants' support for the humans' alignment in the network by guiding their gaze. This activity appeared to be closely connected to the actants' interactions and translations. The non-human actants acted as locators by highlighting functions to guide and lead the gazes of the human actants (the students) as a following act. Excerpt 1.1 shows these activities in the network.

[Note: The transcriptions in the following excerpts are made with Jefferson's (2004) transcription system. Underlined text indicates the speaker is emphasizing or stressing the speech; an up arrow indicates a rising pitch or intonation]

- Excerpt 1.1 - What's your opinion man?

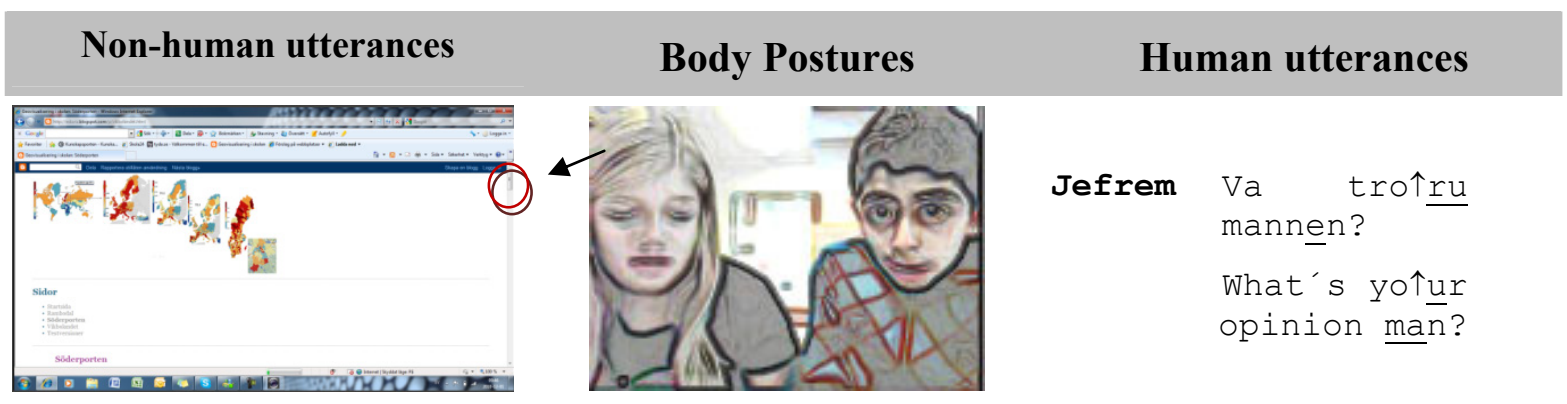



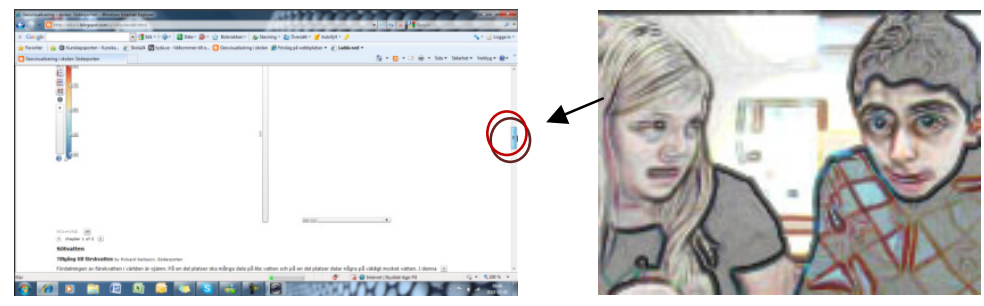

Linn

Jag e en kvinna.

I am a woman.
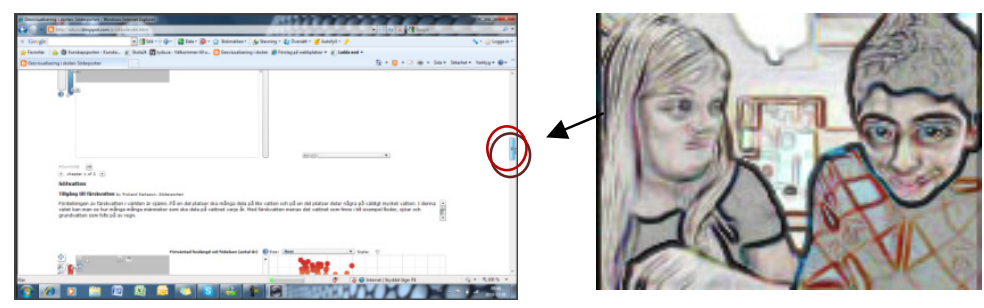

Jefrem
Vad tror $\uparrow \underline{u}$ kär- ring
(.)

What's your

opinion $\overline{\mathrm{COW}}$ (.)
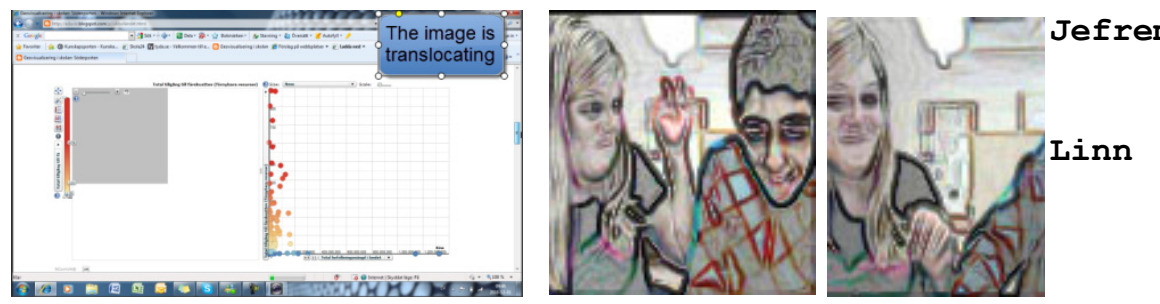

$\mathrm{H}[\mathrm{hh} . .$.

[Mmhf]
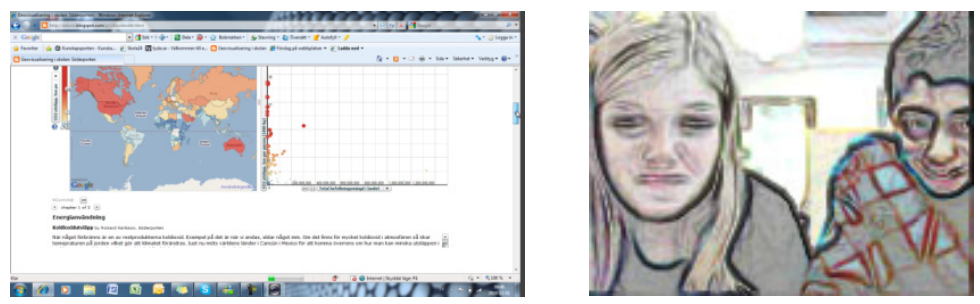

The activity here, despite the squabble, turned out to be about a search for the right place on the website. The students had to find information that helped them to locate this place. So, by adjusting the image of the screen a search began. The articulations on the screen, the cursor and the scroller worked together as highlighters. Jefrem's eyes were concentrated on the motions of the screen during the whole episode, except for a very brief moment. His utterance "What's your opinion man?" was made in an ironic or teasing tone that can be read as indicating that there were few doubts about whether they were at the right place on the web site or not. Overlapping in duration with this utterance, Jefrem moved the hand in which he was holding the mouse. He followed the cursor as a highlighter on the screen. The cursor and Jefrem located the place of the scroller in the scrollbar.

Despite the turbulence, a part of the learning activity can be interpreted as human enrollment; the students were able to find and follow non-human actants' articulations, which were providing highlighting tracks in the form of moving objects on the screen. When Linn realized what Jefrem had said to her, referring to her as "man", she closed her eyes as a pause in the work for reflection. She then put her chin back, leaned her brow forward and told Jefrem in a firm and steady voice that she was a "woman". Simultaneously, without looking at Linn, Jefrem responded to her while following the cursor and scroller on the screen with his gaze. He revised his statement to "What's your opinion cow," which, in itself, is an interesting and complex travesty consisting of interconnected linguistic parts or turns. As Linn perceived and interpreted the comment she looked quickly back and forth between the screen and Jefrem. Meanwhile, the other actants were 
involved in a sequence of activities; Jefrem had moved his hand with the mouse on the table, he had clicked the mouse, he had pressed the button and again his hand moved on the table. The cursor, on the other hand, had moved to the scroller and located itself over the scroller. The cursor on top of the scroller had moved down in the scrollbar. The image on the screen had started to move as a result of these interactions. Jefrem was following all the actions on the screen with his gaze. Linn, however, had formed her face into a ball, her hand was raised and she slapped Jefrem on his shoulder. As she did this, her eyes were smiling. Jefrem seemed to find the situation amusing; he laughed and bent away slightly, but was still holding his hand on the mouse during the episode and was directly aware of where to look at the screen when he straightened up again. His gaze immediately focused on the highlighting scroller that he seemed to be following. Translations between these were made throughout the whole episode. Linn's eyes were also immediately, even before her hand was down after the slap, back on the screen with her gaze. She was focusing on the screen again which then articulated a map together with a scatter plot.

So, with the non-human actants' support, the students were easily able to follow and interpret the information and adjust the screen - the spatial property in virtuality could be determined. They used their visual ability to search, follow, and focus on the coded information articulated and highlighted by the non-human actants. The non-human actants seemed to strengthen the students' ability to focus on the object of knowledge. The interactions and translations in the network reinforced the actants' ability to process information.

\section{Network Collaboration - Human Enrollments Affect Alignment}

The learning activities show how the human actants move back and forth or simultaneously act in activities concerning the object of knowledge and human enrollment. During the turns between the human and non-human actants several close interventions, such as co-collaborations or interactions, were observed, where the non-human actant seems to support the student as they align in the network.

Excerpt $1.2-$ Be pleased!

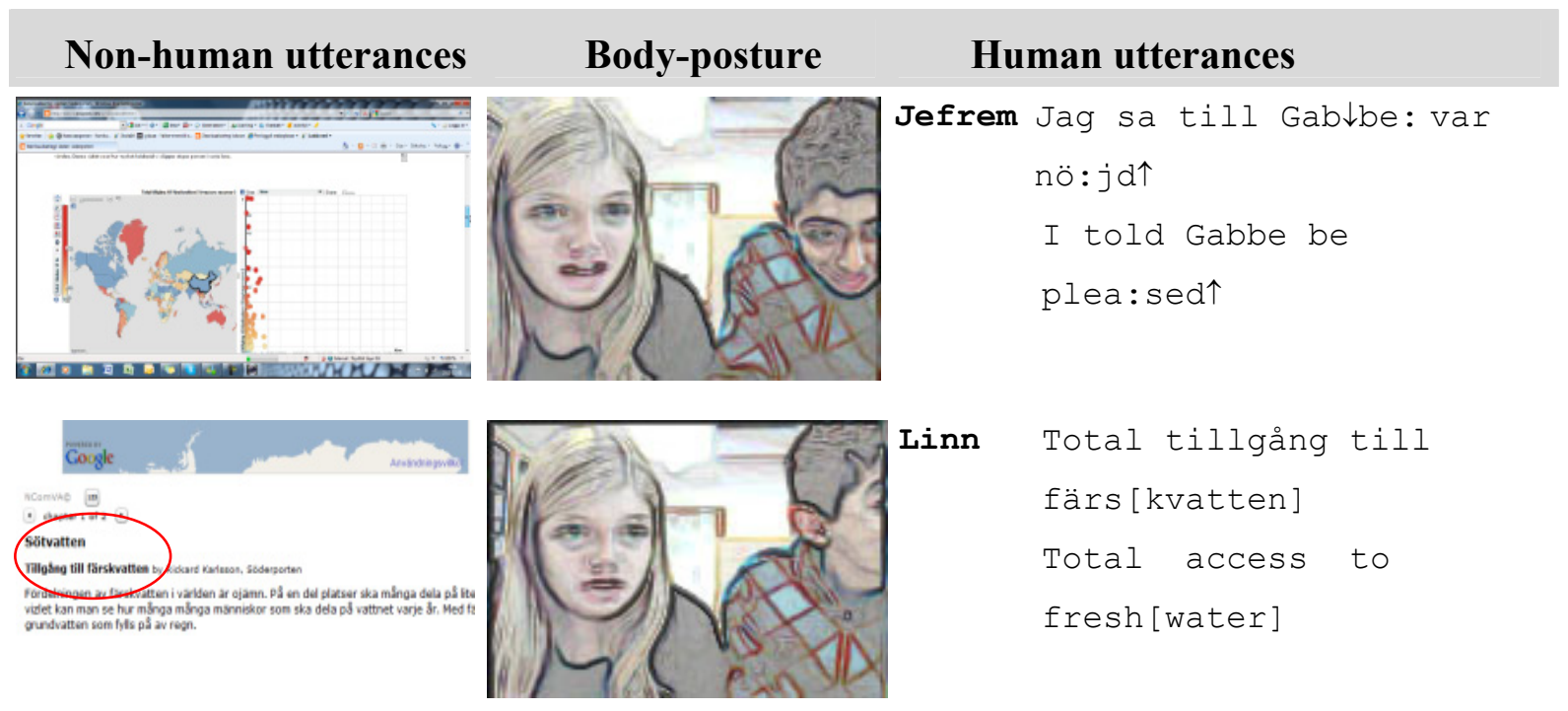



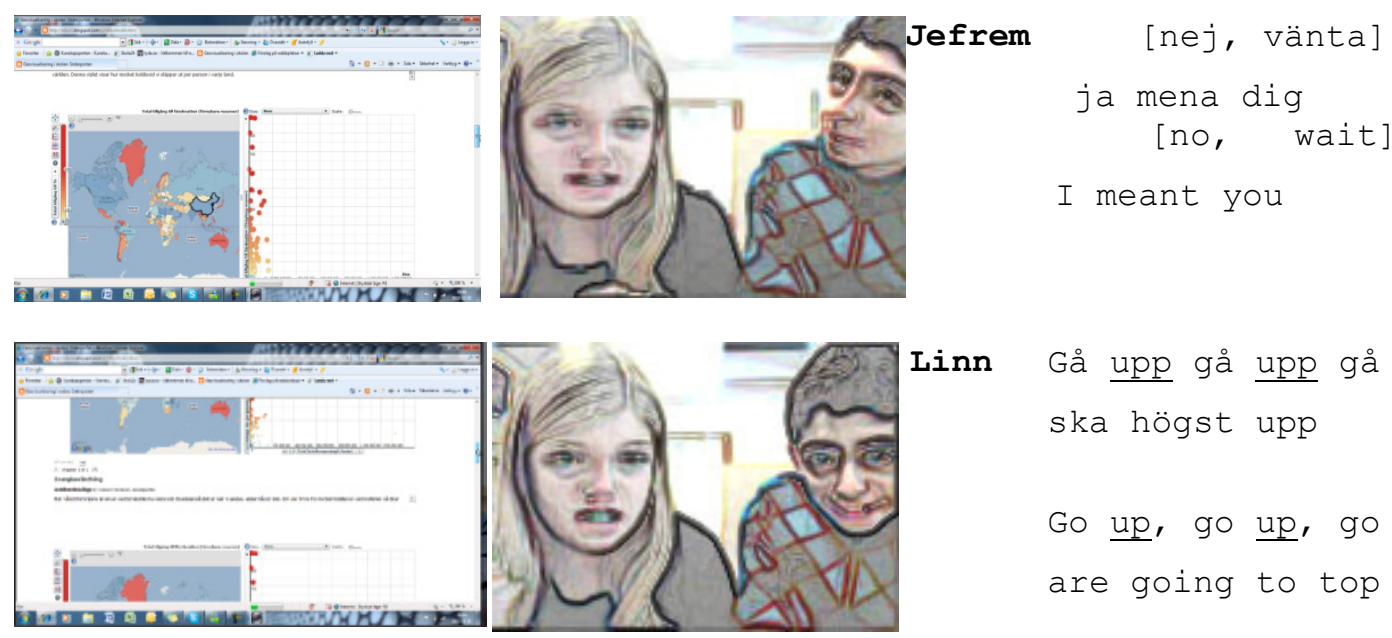

Gå upp gå upp gå upp vi
ska högst upp
Go up, go up, go up, we
are going to top
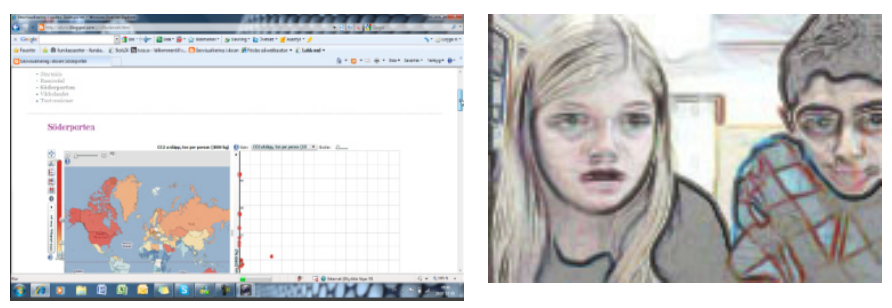

Linn

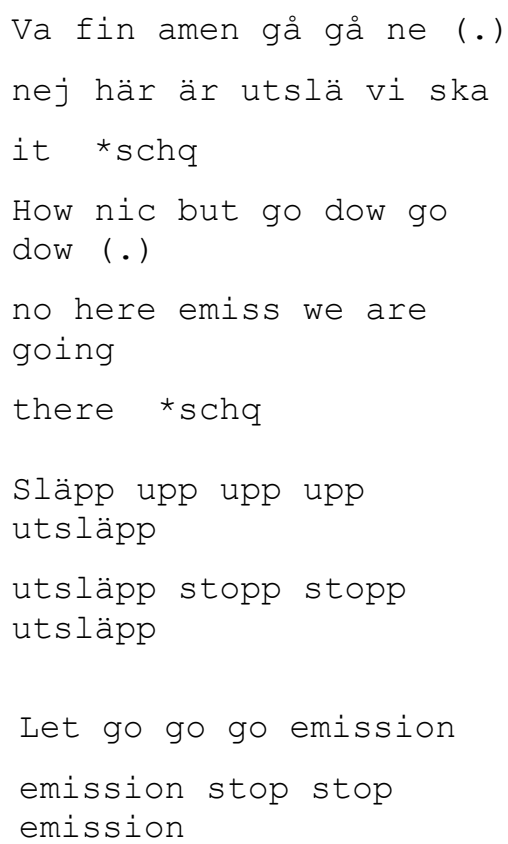

This excerpt shows a close collaboration between all actants. They were all involved in several actions; some of them articulating (text), others focusing, and still others enrolling as human. To begin, Jefrem's explanation that his earlier expression had been addressed not to Linn but to the boy Gabbe, who was sitting next to them, can be read as a negotiation of the interactions in order not to let them cease from Jefrem's side. Jefrem probably tried to get away from the naughty expression and the situation when he told Linn that she should be pleased. He probably also wanted her to negotiate on this. As Jefrem was not sure about what reaction would come from Linn, he prepared for another slap by quickly ducking away. Linn, however, was not paying any attention to him, as if she was trying to disconnect him from the network. This is interpreted as an indication that at this moment there were some trials by strength in the network. Jefrem was therefore enrolling as a negotiating actant in the network as the learning activity continued, and Linn enrolled by ignoring the negotiations as the proud human. Jefrem's enrollments and negotiations continued until he was able to align into the network again; it is interpreted like this: before the image was centered on the screen, Linn focused on an indicator on the screen. The coding the screen used in its articulation of the indicator was text. Linn spelled the word "freshwater" out 
loud, as if she was talking to the screen, still disconnecting Jefrem. Even before she had finished her sentence, Jefrem had changed his mind about whom he was addressing, probably because of the lack of reaction from Linn. In another try, he turned his gaze upwards and with a mischievous smile he addressed the statement to Linn again. She continued to ignore him by slightly looking at the screen, but a change happened when she told Jefrem to move the image on the screen by requesting him to "go up." Jefrem's negotiations finally seemed to bear fruit and Linn was able to negotiate with her pride intact in order to reach the purpose of the learning activity. Being the one directing the mouse seemed to enable Jefrem to connect to the network. As Linn used her ability to focus, she spotted the word "emission" and that was probably a signal to her to stop adjusting the screen. Without any more negotiations between the students, they seem to agree; probably both had focused on the material actants' coding, that is, the text message on the screen - emission - which intervened as the semiotic message. The actants' alignments in the network were again stable.

So, the human actants move back and forth or simultaneously act in activities concerning the $o b$ ject of knowledge and human enrollment. This is seen to indicate that actions of human enrollment are important to be able to align in the network. The frequent negotiations and the actantship can be understood as questions of subjectivity and how to become a subject of actions and responsibility (Masschelein, 2012; Winter \& Biesta, 2012). The negotiations are required by poorly aligned actors; without them the interactions will come to an end (Latour, 1987, pp. 74 79). The Geovisual Analytics, as material actants, seemed to play a supporting role when a human actor almost shut another out. The interactions concerning human enrollment are interpreted as an important strategy enabling the humans to align in/into the network - as the network offers opportunities to find and focus on the object of knowledge.

\section{Network Collaboration - Learning the Object of Knowledge}

This last excerpt shows how the produced translations and alignments in the network support learning the object of knowledge.

Excerpt 1.3 - Qatar, oh my God!

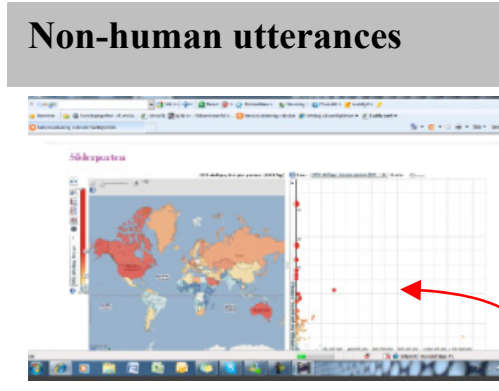

Human body-postures

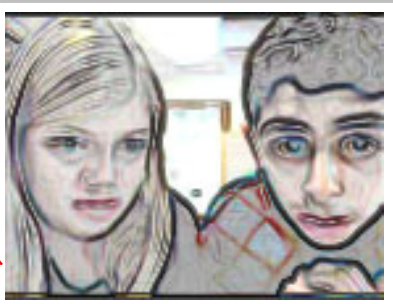

Cursor moves to the left

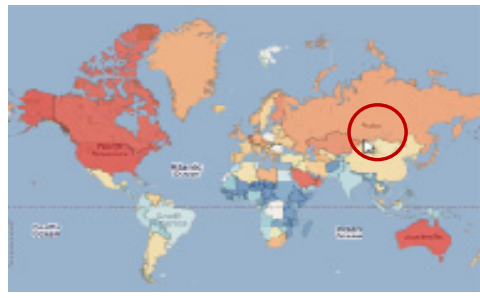

Cursor passes Australia

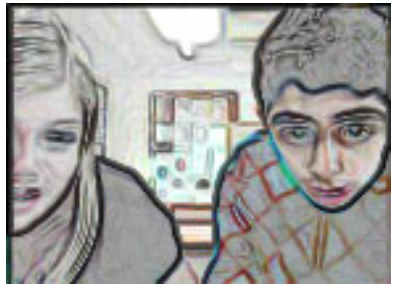

Linn smiles

\section{Human utterances}

Vänta kolla rå

vilket som är störst på klicka på north,

Wait look at what's the biggest click at north

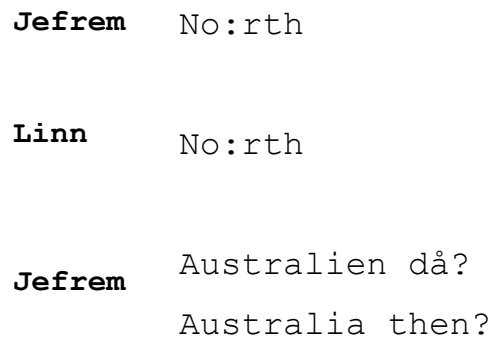



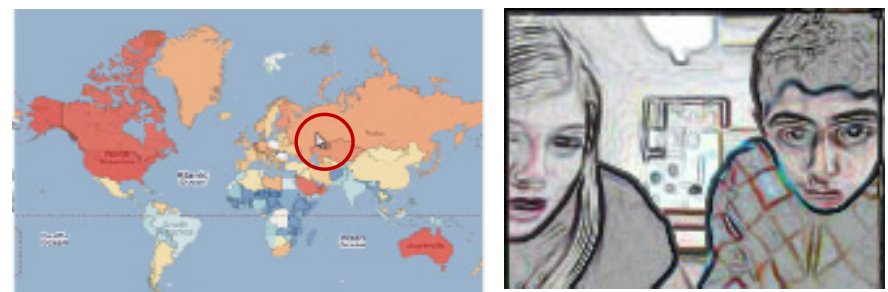

Cursor stops
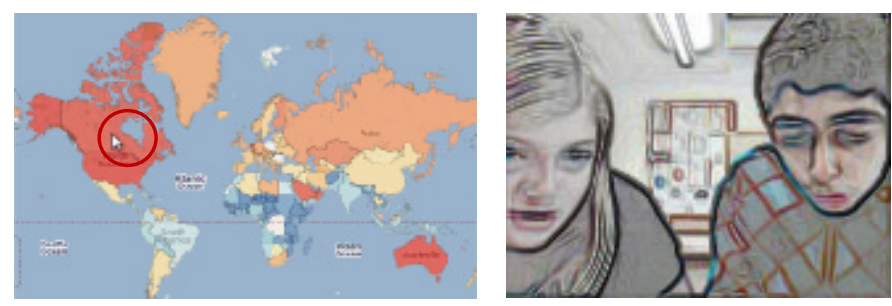

Jefrem's eyes closes
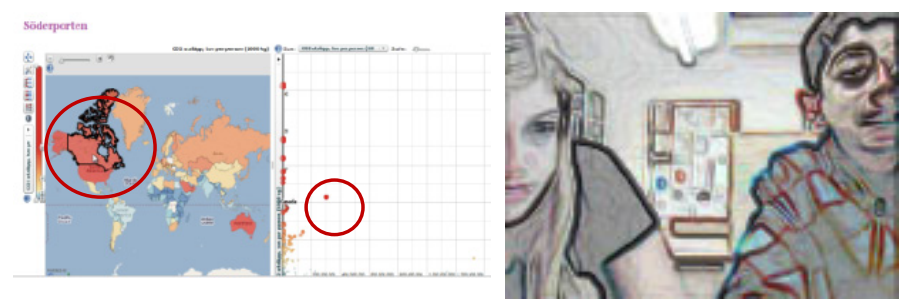

Jefrem

Highlighting Canada

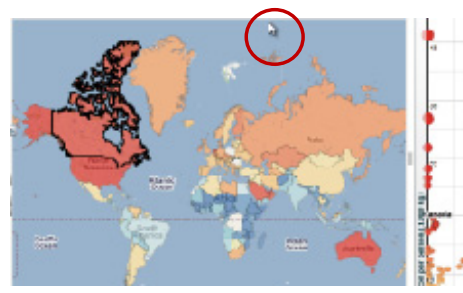

Linn takes the mouse

Cursor moves towards the bubble at the top

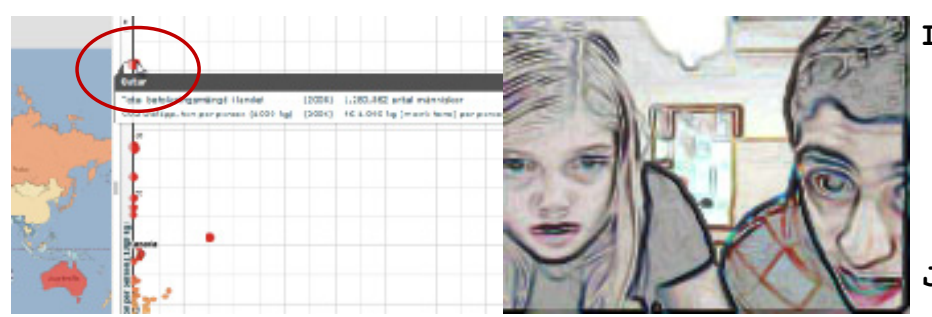

\section{Highlighting Qatar}

Jefrem

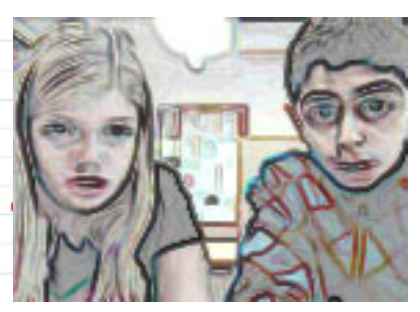

Linn

Iinn

Jefrem
Linn [Klicka bara]

[Just click ]

[Austr

[Austr

Jefrem Klicka bara

Just click

Linn Klicka bara

Just click

Varför det? Jag kan göra det med svensk accent

Why? I can do it with a Swedish accent

Där är Canada men vilken ä störst då?

There is Canada but which is the biggest then?

Jefrem Ja det kan man fråga sig

Yes, that is what you can ask yourself

Qata:r(.) $\quad \cdot \quad$ oh $\uparrow$ herre [min je]

Qata:r(.) $\frac{\text { oh } \uparrow}{[\text { my God }]}$

[Qataa] Qata:r oh den var mycket ut

[Qataa] Qata:r oh that was a high emission level 
The learning activities here were at the same time directed to the object of knowledge and to human enrollment. The content of the talk was oriented to the object of knowledge, but many of the turn takings, imitations, and pronunciations were simultaneously also oriented to human enrollment, all done in a chit-chatting manner.

The object of knowledge in the learning activity was about finding something that was "the biggest." The students were investigating the screen's articulations concerning something that was a vast amount, volume, or quantity. On the screen, the red color articulated on the map called for the students' attention. When Linn asked Jefrem to click on "north," their attention went in two different directions. Linn looked to the left and Jefrem looked to the right, as if they were looking at each one of the two largest areas on the map that were read, North America and Australia. Meanwhile, Jefrem also moved the mouse. The cursor moved from the scrollbar and passed across the middle of the scatter plot. When it passed above Australia, Jefrem asked, "What about that country?" This is interpreted as indicating that Jefrem's vision was not drawn only by the color, but was also directed by the cursor (a following act by a moving object), which was moving from the right to the left on the screen. By following this articulation Jefrem saw Australia first, positioned at the right. Linn, on the other hand, was looking straight to the left, and she spotted and focused on North America first. She was not following the cursor with her gaze. This can be read as indicating that her alignment did not give the same translation in the network as the alignment between the cursor, Jefrem's vision, the mouse, his hand, and the color on the screen, which together can be interpreted as a sort of punctualization, a point where the network provides support so efficiently that it almost disappears from view. The non-human actants helped the students in different ways to remain focused on the screen.

If we look at the same point where Linn asked Jefrem to click on "north," we can see that this learning activity also shows how it is oriented to human enrollment. Jefrem's repetition of this word was pronounced in a syllabic way, with a stressed lisping sound, as if he was imitating the sound that Linn had made. When she repeated the word in her turn, the word was pronounced more smoothly. Happy with that achievement, she smiled to herself. Jefrem's attempt to repeat Linn's "just click," which she had pronounced with a strong local accent, sounded a bit strange to him, as Swedish is not his mother tongue. When he responded to Linn again by asking "Why?" he also pointed out that he could do it with a Swedish accent. These interactions are read as human actants' manifestations of themselves. The imitations back and forth can again be seen as processes of self-creation, how the students are enrolling as emerging, revisable, and fragmented entities (Biesta, 1995). The concurrent focus on the object of knowledge is shown by Jefrem's "Why?" and his body movements as he leans backwards and rubs his eyes. Probably these actions occurred because he did not get any response to his question of why he should click on another area than he had suggested (Australia). As he was oriented to the object of knowledge he wondered why he was supposed to just click, without consideration. Linn was also oriented to the object of knowledge, but concerned with the area she had spotted (North America). She ignored Jefrem and took the mouse and clicked on Canada. These actions can be read as trials of strength appearing in the network again. Canada was, with the "click," marked on the map and in turn the screen articulated and highlighted the country with a black line around the borders on the map and, as the view was dynalinked, a border around the bubble indicating Canada on the scatter plot turned up. Jefrem was able to align into the network again with this articulation. A negotiation of shared interest was made with support of the highlighting effect from this non-human actant. Canada was located at the middle of the $y$-axis with a couple of bubbles above it. Both students seemed surprised to find Canada there and Qatar at the top of the scatter plot, implied by the Linn's short pause. As soon as the students spotted Qatar they seemed to abandon the thought that the red color means the biggest and was connected to area/size. Instead, they both immediately became emotionally involved concerning the large amount of $\mathrm{CO}_{2}$ emissions for which Qatar is responsible. This indicates that they left their first interpretation of the red color's semiotic mean- 
ing as largest area/size and instead adopted the idea that the semiotic message was about volume of $\mathrm{CO}_{2}$ emissions.

To summarize, the interactions distributed in the network can be said to support learning of the object of knowledge, where semiotic messages support and create alignment and the non-human actants reinforce alignment and human enrollment affects alignment. By taking part in the organized way of producing and understanding actions and events that were answerable to educational and the students' distinctive interests, the actants can, supported by the network, be said to perform proficiently and competently.

\section{Conclusions}

The results show that education involving Geovisual Analytics produces learning activities that provide students with some advantages.

First, it provides opportunities to handle vast amounts of data. The students were able to handle the data-rich setting as they encountered and translated with the multimodal signs: they visualized data, text information, and other traits of the tool. The students' information skills, vision, and competence were developed in close collaboration with non-human actors: the task, the data/information, and the tool. The Geovisual Analytics tool directed the students to look at the screen in certain ways and to see relevant events within it. Commonly the interactions - coding, highlighting, and articulation - were found to be linked to actions on the screen. These concepts can also be found in Goodwin's framework (Goodwin, 1994) but are then associated with social practices. This study suggests that other concepts - searching, following, and focusing - are to be seen here as originating from human actants. These concepts are interpreted as more open and flexible in their appearance than the ones that are more connected to the screen. Together, the interactions between these were intertwined in different sorts of translations among the actants. The translations produced alignments, which can be described as nodes, constituting a heterogeneously constructed network - providing the education.

Second, it supports participation in the learning activities. The students are, by means of the technology and each other, able to participate and act in the learning activities. The actors are dependent on everybody's abilities to collaborate/negotiate, translate, and align in the networks. The non-human actants, the visual information, and the semiotics helped and strengthened the students' ability to take part in the learning activities. Together, the data-rich setting and the students create intelligibility, where knowledge emerged from the learning activities and therefore the support of the ability to take part in the learning activities is central. The learning activities - the networks - supply the students with a knowledge of seeing that situates the events visible on the screen within the work life of the particular community of students in this educational setting (Goodwin, 1994). When data are transformed into visual information - when certain content is processed - the purpose of learning can be said to be supported by the Geovisual technology and the education produced can also be seen as framed (Biesta, 2009).

Third, it provides benefits to achieve various educational purposes. In line with Osberg and Biesta (2008), the students' purposes in taking part in the learning activities were both to enroll as humans and to learn some content. The purpose of enrolling as human appears, for the students in this study, to prevail over the purpose concerning the content, as this seemed to enable the students to take part in and act in the network. The results therefore call into question Carroll's Time-On-Task hypothesis (Bloom, 1982; Carroll 1963). The results indicate that the off-task behavior, exemplified by activities of human enrollment, are ongoing and performed at the same time as the activities related to the object of knowledge, which corresponds well with Benwell and Stokoe (2005) and Barajas (2010). It is recommended that time spent in off-task behavior/human enrollment is instead seen to be as crucial as the time spent on the object of knowl- 
edge. Hence, not only is the purpose of education diverse, but also the process undertaken to achieve the purpose of education is diverse for different actors (Ludvigsen, 2011). Thus, the Geovisual Analytics tool prompts the students to simultaneously take part in the processes of attending to the content and to human enrollment by offering highlights to search for, follow, and focus on during the activity. The students are empowered by the technology to achieve their diverse purposes.

To sum up, the learning activities have been shown to be deeply intertwined as networks in terms of nodes and can be said have as many dimensions as they have connections. We can speak about learning as a multiple phenomenon, complex in character, continuously ongoing in an intertwined, multimodal, and content-focused mode. The reality seems to be that designs for learning may adapt and include a variety of tools, combinations of modalities, levels of interactivity, learner characteristics, and pedagogy based on a complex set of circumstances (Fadel, 2008). The paper argues that the use of Geovisual Analytics in the classroom indeed affects learning and, as Halverson and Shapiro (2012) argue, knowledge about such phenomena can demonstrate and help to reshape education. Due to the close collaboration between the actants in the networks, it is vital to investigate these learning activities further to find out more about the alliance of data and information processing, the problem areas, and the task complexity that can occur. The combined effects of this shift in data communication and data use that the technology offers may probably produce a deep change in human, cultural, and bodily engagement with the world and the forms and shapes of knowledge.

\section{Acknowledgments}

The research was supported in part by funding from the Research School of Childhood, Learning and Didactics (RSCLD), Educational Sciences (grant No. 721-2007-3671), and the Swedish Agency for Innovation Systems (VINNOVA). The author thanks in particular the teachers who contributed and the students who participated in the study, as well as the entire research team at NComVA for their valuable contributions.

\section{References}

Ainsworth, S. (2008). How should we evaluate multimedia learning environments? In J. Rouet, R. Lowe, \& W. Schnotz (Eds.), Understanding multimedia documents (pp. 249-265). USA: Springer.

Andrienko, G., Andrienko, N., Demsar, U., Dransch, D., Dykes, J., Fabrikant, S. R., ... Tominsk, C.. (2010). Space, time and visual analytics. International Journal of Geographical Information Science [Special Issue: Geospatial Visual Analytics: Focus on Time Special Issue of the ICA Commission on GeoVisualization], 24(10), 1577-1600.

Angrist, J., \& Lavy, V. (2002). New evidence on classroom computers and pupil learning. The Economic Journal, 112(482), 735-765.

Barajas, K. E. (2010). The pimp and the happy whore: "Doing gender" in film talk in a school setting. Scandinavian Journal of Educational Research, 54(6), 581-596.

Benwell, B., \& Stokoe, E. H. (2005). University students resisting academic identity. In K. Richards \& P. Seedhouse (Eds.), Applying conversation analysis (pp. 124-139). Basingstoke, UK: Palgrave Macmillan.

Biesta, G. (1995). Postmodernism and the repoliticization of education. Interchange, 26(2), 161-83.

Biesta, G. (2009). Theorizing learning through complexity: An educational critique. A response to Ton Jörg's programmatic view. Complicity, 6(1), 28-33. Retrieved from http://ejournals.library.ualberta.ca/index.php/complicity/article/view/8802/7122 
Bijker, W. E. (2010). How is technology made? That is the question. Cambridge Journal of Economics, 34(1), 63-76.

Bloom, B. S. (1982). Human characteristics and school learning. New York: McGraw-Hill.

Byström, K. (1999). Task complexity, information types and information sources: Examination of relationships. Tampere: University of Tampere.

Callon, M. (1986). Some elements of a sociology of translation: Domestication of the scallops and the fishermen of St Brieuc Bay. In J. Law (Ed.), Power, action, and belief: A new sociology of knowledge (pp. 196-233). London: Routledge \& Kegan Paul.

Carroll, J. B. (1963). A model of school learning. Teachers College Record, 64, 723-733.

Chakravarty, R. (2008). Information literacy in the knowledge society: Empowering learners for a better tomorrow. In Trends and Strategic Issues for Libraries in Global Information Society: Proceedings of the ICSSR Sponsored Seminar held on March 18-19, 2008 at Panjab University, Chandigarh Patiala: Twenty First Century Publications, pp. 303-314.

Charters, E. (2003). The use of think-aloud methods in qualitative research: An introduction to think-aloud methods. Brock Education, 12(2), 68-82.

Djonov, E., \& Van Leeuwen, T. (2011). The semiotics of texture: From tactile to visual communication. Visual Communication, 10, 510-564.

Edwards, R., Biesta, G., \& Thorpe, M. (2009). Rethinking contexts for learning and teaching. New York: Routledge.

Engestrom, Y., \& Miettinen, R. (1999). Introduction: Activity Theory: A well kept secret. In Y. Engestrom, R. Miettinen, \& R. Punamaki (Eds.), Perspectives of activity theory (pp. 1-16). Cambridge: Cambridge University Press.

Fadel, C. (2008). Multimodal learning through media: What the research says. Global Lead, Education, Cisco Systems Inc.

Fenwick, T. J., \& Edwards, R. (2010). Actor-network theory in education (1st ed.). London; New York: Routledge.

Goodwin, C. (1994). Professional vision. American Anthropologist, 96(3), 606-633.

Hackman, J. R. (1969). Toward understanding the role of tasks in behavioral research. Acta Psychologica, 31, 97-128.

Halverson, R., \& Shapiro, R. B. (2012). Technologies for education and technologies for learners: How information technologies are (and should be) changing schools. (WCER Working Paper no. 2012-6). Retrieved from University of Wisconsin-Madison, Wisconsin Center for Education Research Website: http://www.wcer.wisc.edu/publications/workingPapers/papers.php

Harper, R., Rodden, T., Rogers, Y., \& Sellen, A. (2008). Being human: Human-computer interaction in the year 2020. Cambridge, England: Microsoft Research Ltd.

Heath, C., Hindmarsh, J., \& Luff, P. (2010). Video in qualitative research: Analysing social interaction in everyday life. Los Angeles: SAGE.

Heidegger, M. (1977). The question concerning technology, and other essays (1st ed.). New York: Harper \& Row.

Hilbert, M., \& López, P. (2011). The world's technological capacity to store, communicate, and compute information. Science, 332(6025), 60-65. doi:10.1126/science.1200970

Ho, Q., Lundblad, P., Åström, T., \& Jern, M. (2011). A web-enabled visualization toolkit for geovisual analytics visualization and data analysis. Proceedings of SPIE: Electronic Imaging Science and Technology, Visualization and Data Analysis, San Francisco, Jan 2011. 
Jefferson, G. (1985). An exercise in the transcription and analysis of laughter. In T. Van Dijk (Ed.), Handbook of discourse analysi, (Vol.3 Discourse and dialogue), pp. 25-34. London, UK: Academic Press.

Jefferson, G. (2004). Glossary of transcript symbols with an introduction. In G. H. Lerner (Ed), Conversation analysis: Studies from the first generation (pp. 13-31). Amsterdam/Philadelphia: John Benjamins.

Jern, M. (2010). Collaborative educational geoanalytics applied to large statistics temporal data. Paper presented at CSEDU 2010 - 2nd International Conference on Computer Supported Education, 233-238. Retrieved from SCOPUS database.

Jordan, B., \& Henderson, A. (1995). Interaction analysis. Foundations and Practice, 4(1), 39-103.

Keim, D., Andrienko, G., Fekete, J., Görg, C., Kohlhammer, J., \& Melançcon, G. (2008). Visual analytics: Definition, process, and challenges information visualization. In A. Kerren, J. Stasko, J. Fekete, \& C. North (Eds.), Information visualization (pp. 154-175). Berlin, Heidelberg: Springer.

Kress, G. R. (2010). Multimodality: A social semiotic approach to contemporary communication. London: Routledge.

Lantz-Andersson, A. (2009). Framing in educational practices: Learning activity, digital technology and the logic of situated action. Göteborg: Acta Universitatis Gothoburgensis.

Latour, B. (1987): Science in action: How to follow scientists and engineers through society. Cambridge, MA: Harvard University Press.

Latour, B. (1992). Where are the missing masses? The sociology of a few mundane artefacts. In W. Bijker \& J. Law (Eds.), Shaping technology/building society: Studies in sociotechnical change (pp. 225-258). Cambridge, Mass.: MIT Press.

Latour, B. (1996). On interobjectivity. [Special symposium with discussion by Marc Berg, Michael Lynch, and Yrjo Engelström and a response by the author.] Mind, Culture and Activity, 3(4), 228-255-246269.

Latour, B. (2007). Reassembling the social: An introduction to actor-network-theory. Oxford: Oxford University Press.

Lave, J., \& Wenger, E. (1991). Situated learning: Legitimate peripheral participation. Cambridge: Cambridge University Press.

Law, J. (1992). Notes on the theory of the actor-network: Ordering, strategy, and heterogeneity. Systems Practice, 5(4), 379-393.

Law, J., \& Hassard, J. (1999). Actor network theory and after. Oxford: Blackwell.

Limberg, L., Alexandersson, M., \& Lantz Andersson, A. (2008). To be lost and to be a loser through the Web. In T. Hansson (Ed.), Handbook of digital information technologies: Innovations, methods, and ethical issues. IGI Global: Hershey, PA.

Ludvigsen, S. R. (2011). What counts as knowledge: Learning to use categories in computer environments. Learning, Media and Technology, 37(1), 40- 52. doi: 10.1080/17439884.2011.573149

Manyika, J. Chui, M., Brown, B., Bughin, J., Dobbs, R., Roxburgh, C., \& Byers, A. H. (2011). Big data: The next frontier for innovation, competition, and productivity. McKinsey Global Institute.

Masschelein, J. (2012). Experimentum scholae: The world once more ... but not (yet) finished. Studies in Philosophy and Education, 30(5), 529-535.

Mercer, N. (1995). The guided construction of knowledge: Talk among teachers and learners. Clevedon: Multilingual Matters.

Osberg, D. C., \& Biesta, G. J. J. (2008). The emergent curriculum: Navigating a complex course between unguided learning and planned enculturation. Journal of Curriculum Studies, 40(3), 313-328.

Pinch, T. J., \& Bijker, W. (1987). The social construction of facts and artifacts or how the sociology of science and the sociology of technology might benefit each other. In E. Wiebe, Bijker, P. Thomas, 
Hughes, J. Trevor, \& T. J. Pinch (Eds.), The social construction of technological systems: New directions in the sociology and history of technology (pp. 17-50). Cambridge, MA: MIT Press.

Rouse, C. E., Krueger, A. B., \& Markham, L. (2004). Putting computerized instruction to the test: A randomized evaluation of a 'scientifically-based' reading program, (No. 10315). National Bureau of Economic Research.

Stenliden, L. (2011). Geovisualisering i skolan [Geovisualization in school]. Retrieved 10/01/2011, from http://eduviz.blogspot.com

Stenliden, L., \& Jern, M. (2010). Educating official statistics using geovisual analytics storytelling methods. INTED2010 Proceedings, Valencia, pp. 2736-2744.

Sundin, O., \& Johannisson, J. (2005). The instrumentality of information needs and relevance. Proceedings of Context: Nature, Impact, and Role - 5th International Conference on Conceptions of Library and Information Sciences, CoLIS 2005, Glasgow, UK, June 4-8, 2005.. pp. 107.

Sundin, O., Julien, H., Limberg, L., \& and Rieh, S. Y. (2008). Credibility and authority of information in learning environments. Proceedings of the American Society for Information Science and Technology, $45(1-5$

Takayoshi, P., \& Selfe, C. L. (2007). Thinking about multimodality. In C. L. Selfe (Ed.), Multimodal composition: Resources for teachers (pp. 1-12). New York NY: Hampton Press, Inc.

Tomaszewski, B. (2008). Producing geo-historical context from implicit sources: A geovisual analytics approach. Cartographic Journal, 45(3), 165.

Tucker, B. (2010). Putting data into practice: Lessons from New York City. Washington, DC: Education Sector:

Winter, P., \& Biesta, G. (2012). Coming into the world, uniqueness, and the beautiful risk of education. An interview with Gert Biesta by Philip Winter. In G. J. J. Biesta (Ed.), Making sense of education (pp. 109-114) Netherlands: Springer.

\section{Biography}

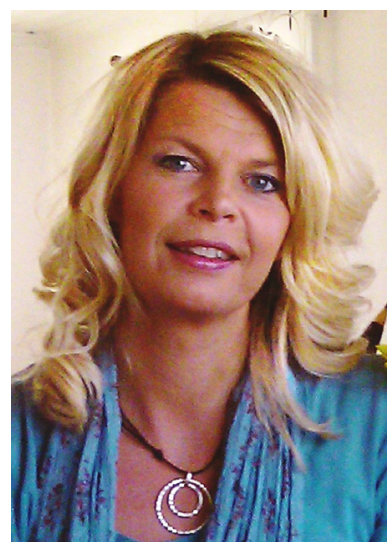

Linnea Stenliden is a Lecturer in Teacher Training Education at Linköping University, in Sweden. Her qualifications include a MEd from the same university and she is in the final year of her PhDproject. Her background is in the field of educational design, academic development and educational technology and she has multidisciplinary qualifications in education, information technology and educational multimedia. In her current role she also provides academic leadership and expertise in online and blended learning and the application of new technologies to support student learning. She has led a wide range of teaching and learning initiatives and her research interests are in the field of online learning, visual analytics, geovisual analytics, learning analytics and new generation learning. 